\title{
ВАЗОМОТОРНА ФУНКЦІЯ ЕНДОТЕЛІЮ У МОЛОДИХ ОСІБ РІЗНОГО СОМАТОТИПУ 3 НОРМАЛЬНИМ ТА ПІДВИЩЕНИМ АРТЕРІАЛЬНИМ ТИСКОМ
}

\author{
С.Н. Вадзюк, Л.І. Горбань, І.Я. Папінко
}

Тернопільський національний медичний університет ім. І.Я. Горбачевського, кафедра фізіологї з основами біоетики та біобезпеки, м. Тернопіль, Україна, ORCID ID: 0000-0001-9105-8205,e-mail:vadzyuk@tdmu.edu.ua, ORCID ID:0000-0002-8572-239X, e-mail: horban@tdmu.edu.ua, ORCID ID:0000-0001-6129-0097,e-mail:papinko@tdmu.edu.ua

Резюме. Мета роботи - оцінити вазомоторну функцію ендотелію у молодих осіб віком 18-22 роки різного соматотипу з нормальним та підвищеним артеріальним тиском (АТ).

Матеріали і методи дослідження. Відібрано дві групи обстежуваних: перша контрольна група - особи, у яких величина АТ відповідала оптимальному рівню (125 осіб), друга група - систолічний АТ перевищував 130 мм рт. ст. і (або) діастолічний - 85 мм рт. ст. (135 осіб). Соматотип визначали за методикою Carter i Heath, яка рекомендована для осіб обох статей віком від 14 до 70 років. Соматотипування полягає у визначенні трьох компонентів: ендоморфія, мезоморфія та ектоморфія, які виражаються завжди в тому ж порядку. Оцінку вазомоторної функції ендотелію проводили за допомогою проби з постоклюзивною реактивною гіперемією, згідно з методикою Рогози та Заірової (2011).

Результати. Встановлено збільшення частоти розвитку дисфункції ендотелію у молодих осіб, у соматотипі яких переважав ендоморфний компонент. Це може бути пов'язано із зменшенням продукції оксиду азоту, що зумовлює дисбаланс між вазоконстрикторами і вазодилятаторами. Зниження концентрації оксиду азоту у цих осіб може бути спричинено зменшенням активності NO-синтетази (NOS).

Висновки. У молодих осіб з підвищеним артеріальним тиском та переважанням ендоморфної складової в соматотипі встановлено зниження вазомоторної функції ендотелію, що вказує на зменшення синтезу оксиду азоту ендотеліальними клітинами, що може бути спричинено як конституційними характеристиками, так i особливостями способу життя цих осіб. Серед осіб із нормальним артеріальним тиском та з переважанням ендоморфної складової соматотипу також виявлено зниження вазомоторної функції ендотелію, проте відсоток таких обстежених був істотно нижчим, порівняно із групою підвищеного артеріального тиску.

Ключові слова: артеріальний тиск, артеріальна гіпертензія, ендотелій, вазомоторна функція ендотелію, соматотип.

Вступ. Серед найбільш поширених неінфекційних хронічних патологій чільне місце займають хвороби системи кровообігу, у тому числі артеріальна гіпертензія (АГ), котра є важливим чинником інвалідизації і смертності населення. На етапі сьогодення все більше зростає інтерес до функції ендотелію у хворих на АГ, який відіграє важливу роль у регуляції судинного тонусу та системи гемостазу [1]. Також ендотелій бере участь в активації ренінангіотензинової та симпатичної систем, перемиканні активності на синтез оксидантів, вазоконстрикторів, тромбогенних факторів через ушкодження його в деяких судинних областях [2]. Основним гуморальним чинником ендотелію, що відіграє провідну роль у регуляції тонусу судин, є оксид азоту (NO). NO $є$ ефективним вазодилататором, а його вплив не обмежується дилатацією локальної ділянки. Дисфункція ендотелію - це дисбаланс між продукцією вазодилятуючих, ангіопротективних, антипроліферативних факторів з одного боку і вазоконстрикторних, протромботичних, проліферативних факторів - 3 іншого [3]. Провідним механізмом, що лежить в основі ендотеліальної дисфункції (ЕД), є зниження утворення i біодоступності NO [4]. У фізіологічних умовах NO постійно бере участь в адаптації судинної системи до підвищених метаболічних потреб та фізичного навантаження. Визначено наявність ураження ендотелійзалежної вазодилатації при есенціальній гіпертензії, що зумовлено порушенням синтезу і вивільненням оксиду азоту [5]. Встановлено наявність ураження ендотелійзалежної вазодилатації (ЕЗВД) при АГ, яка зумовлена порушенням синтезу та вивільненням NO [6]. Окрім прямої дії на гладком'язові клітини, оксид азоту здійснює вплив на судинний тонус і через автономну нервову систему. NO в основному пригнічуе активність симпатичного відділу й спричиняє депресорний вплив [3]. Деякі дослідження показують, що ЕЗВД порушується раніше, ніж з'являються клінічні та морфологічні ознаки АГ [7].

Також існує припущення, що ЕД може бути первинним, генетично детермінованим феноменом, оскільки 30-40 \% випадків первинної АГ зумовлені генетичними факторами. ЕД виявляють у нормотензивних родичів хворих на АГ, наведено високий асоціативний зв'язок ЕД з розвитком і прогресуванням АГ [4].

Обгрунтування дослідження. Враховуючи те, що кожному із конституційних типів (сомато- 
типів) притаманні характерні особливості не тільки в антропометричних показниках, але i в діяльності нервової, гуморальної, серцево-судинної та імунної систем, структури та функцій внутрішніх органів [8], можна припустити, що представники певних соматотипів мають різну схильність до появи ЕД та різний іiі перебіг, залежно від рівня артеріального тиску (АТ). Оскільки ендотеліальна дисфункція вважається незалежним предиктором серцево-судинних подій поряд iз традиційними факторами [9], раннє іï виявлення $\epsilon$ особливо актуальним, особливо серед молодих осіб різних соматотипів 3 нормальним та підвищеним артеріальним тиском.

Мета дослідження. Оцінити вазомоторну функцію ендотелію у молодих осіб віком 18-22 роки різного соматотипу 3 нормальним та підвищеним артеріальним тиском.

Матеріали і методи дослідження. Проведені нами дослідження не суперечать прийнятим біоетичним нормам Гельсінської декларації, прийнятої Генеральною асамблеєю Всесвітньої медичної асоціації про права людини, Міжнародному кодексу медичної етики та законам України і можуть бути використані в науковій роботі (рішення комісії з біоетики Тернопільського національного медичного університету імені І.Я. Горбачевського МОЗ України, протокол № 54 від 27 серпня 2019 р.).

Дослідження проводилося на базі атестованої MO3 України лабораторії психофізіологічних досліджень кафедри фізіології з основами біоетики та біобезпеки Тернопільського національного медичного університету імені I. Я. Горбачевського MO3 України (Свідоцтво № 055/13).

Було відібрано дві групи обстежуваних віком від 18 до 22 років. До першої контрольної групи (КГ) були віднесені особи, у яких величина АТ відповідала оптимальному рівню за класифікацією ВОО3 (125 обстежених). Другу групу склали особи, у яких на момент дослідження систолічний АТ перевищував 130 мм рт. ст. і (або) діастолічний - 85 мм рт. ст. (135 осіб). АТ вимірювали методом Короткова у спокійному стані після 5-хвилинного відпочинку. Реєстрували середній результат, після трикратного вимірювання [10].

Соматотип обстежуваних визначали за методикою Carter i Heath [11], яка рекомендована для осіб обох статей віком від 14 до 70 років і $є$ найбільш поширеною на сьогодні. Соматотип - це кількісне відображення існуючої форми та складу людського тіла. Соматотипування полягає у визначенні трьох компонентів: ендоморфія, мезоморфія та ектоморфія, які виражаються завжди в тому ж порядку. Ендоморфія відображає загальний вміст жиру в організмі, мезоморфія характеризує розвиток скелетних м'язів, а ектоморфія відображає стрункість тіла та міру його видовженості. За допомогою певних формул та схеми соматотипування об'єктивно встановлюється соматотип людини.

При характеристиці виділених нами саме змішаних соматотипів переважаючий компонент стоїть на другому місці, а наступний, більший, на першому, третій компонент не озвучується, оскільки він складає найменшу частку в соматотипі.

Оцінку вазомоторної функції ендотелію проводили за допомогою проби 3 постоклюзивною реактивною гіперемією (ПРГ), відповідно до методики Рогози та Заірової (2011) [12]. Для цього використовували комп'ютерний реографічний комплекс «Реоком» (виробництва НТЦ «ХАИ-Медика» Харків, Україна). Після 10-ти хвилинного відпочинку обстежуваного вкладали на кушетку на спину. Застосовували стрічкоподібні, спарені електроди, які накладали на ділянку правої кисті, попередньо шкіру знежирювали $70 \%$ розчином етилового спирту та вимірювали відстані між електродами. На рівні середньої третини передпліччя праворуч накладали оклюзійну манжетку, на ліве плече накладали манжетку тонометра для вимірювання артеріального тиску.

Проводили реєстрацію реовазограми (РВГ) кисті у вихідному стані протягом 5-ти хвилин, перед цим вимірювали вихідний рівень АТ (два виміри). Опісля в оклюзійну манжетку на 5 хвилин нагнітали повітря з тиском, який перевищував величину систолічного АТ на 50 мм рт. ст. і протягом 5-ти хвилин оклюзї проводили контроль рівня артеріального тиску обстежуваного (два виміри). Після різкої декомпресії протягом наступних 5-ти хвилин продовжували реєстрацію РВГ в періоді постоклюзивної реактивної гіперемії (ПРГ), а також проводили контроль рівня АТ (три виміри).

Оцінку вазомоторної функції ендотелію (ВФЕ) проводили за показником відносного приросту амплітуди основної хвилі реовазограми кисті до вихідного значення, який визначали за формулою:

$$
\Delta A \%=\frac{A 2-A 1}{A 1} * 100 \%,
$$

де $\Delta \mathrm{A} \%$ - відносний приріст амплітуди реовазограми, в \%;

А1 - амплітуда основної реовазограми у вихідному стані, в Ом;

А2 - амплітуда основної реовазограми на 3-й хв ПРГ, в Ом.

Приріст показника більше 23,2 \% свідчив про нормальну ВФЕ, а при значенні менше 23,2 \% - про порушення ВФЕ [12].

Результати дослідження статистично обробляли за допомогою ліцензійного програмного статистичного пакету Analyst Soft Stat Plus 6 (№ ліцензії 11895400).

Результати дослідження. За допомогою методики соматотипування серед усіх обстежених нами виділено 6 змішаних соматотипів: мезоморфний ендоморф, мезоморфний ектоморф, ендоморфний мезоморф, ектоморфний ендоморф, ендоморфний ектоморф, ектоморфний мезоморф. 
Таблиця 1

Амплітуда систолічної хвилі реовазограми кисті у вихідному стані та при проведенні проби 3 постоклюзивною реактивною гіперемією в осіб різних соматотипів 3 нормальним та підвищеним АТ

\begin{tabular}{|c|c|c|c|c|c|c|}
\hline \multirow{2}{*}{ Соматотип } & \multicolumn{5}{|c|}{ Амплітуда систолічної хвилі, Ом (М \pm m) } \\
\cline { 2 - 7 } & $\mathrm{n}$ & Вихідний стан & $\begin{array}{c}\text { Реактивна } \\
\text { гіперемія }\end{array}$ & $\mathrm{n}$ & Вихідний стан & Реактивна гіперемія \\
\cline { 2 - 7 } & 23 & $0,049 \pm 0,002$ & $0,073 \pm 0,005$ & 30 & $0,056 \pm 0,007$ & $0,066 \pm 0,007$ \\
\hline $\begin{array}{c}\text { Мезоморфний } \\
\text { ендоморф }\end{array}$ & 20 & $0,054 \pm 0,003$ & $0,078 \pm 0,003$ & 20 & $0,063 \pm 0,004$ & $0,088 \pm 0,004$ \\
\hline $\begin{array}{c}\text { Мезоморфний } \\
\text { ектоморф }\end{array}$ & 22 & $0,048 \pm 0,004$ & $0,072 \pm 0,006$ & 25 & $0,055 \pm 0,004$ & $0,065 \pm 0,005$ \\
\hline $\begin{array}{c}\text { Ендоморфний } \\
\text { мезоморф }\end{array}$ & 20 & $0,047 \pm 0,003$ & $0,073 \pm 0,006$ & 20 & $0,053 \pm 0,005$ & $0,064 \pm 0,006$ \\
\hline $\begin{array}{c}\text { Ектоморфний } \\
\text { ендоморф }\end{array}$ & 20 & $0,055 \pm 0,004$ & $0,085 \pm 0,008$ & 20 & $0,065 \pm 0,007$ & $0,087 \pm 0,008$ \\
\hline $\begin{array}{c}\text { Ендоморфний } \\
\text { ектоморф }\end{array}$ & 20 & $0,052 \pm 0,003$ & $0,077 \pm 0,004$ & 20 & $0,059 \pm 0,006$ & $0,079 \pm 0,008$ \\
\hline $\begin{array}{c}\text { Ектоморфний } \\
\text { мезоморф }\end{array}$ & & & \\
\hline
\end{tabular}

Примітка. Інтерпретація результатів наведена в тексті.

Практично у всіх мезоморфних ектоморфів 3 нормальним АТ приріст амплітуди систолічної хвилі перевищував 23,2\%, що відповідало нормальній ВФЕ, тільки в одного обстеженого виявлено порушення вазомоторної функції ендотелію (5\%). Серед ектоморфних та ендоморфних мезоморфів КГ виявлено по 2 обстежених із порушеною ВФЕ у кожному із соматотипів, що становило по $10 \%$ від усіх представ-

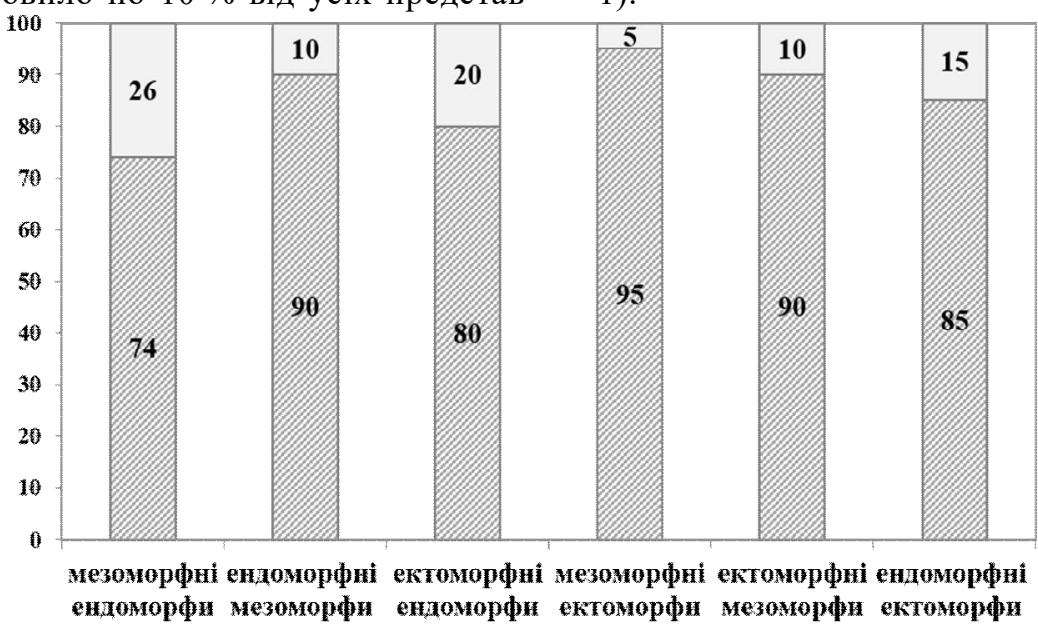

\section{$\square$ Порушена ВФЕ}

Рис. 1. Стан вазомоторної функції ендотелію судин після проведення проби з постоклюзивною реактивною гіперемісю в осіб різних соматотипів 3 нормальним АТ.

В обстежених мезоморфних ендоморфів 3 підвищеним АТ нормальна ВФЕ встановлена у 46,7 $\%$, а порушення ВФЕ зафіксовано у 53,3 \% осіб цього соматотипу. Також погіршення ВФЕ виявлено у 60 \% представників ендоморфних мезоморфів і ектоморф- ників цих соматотипів. У групі ендоморфних ектоморфів 3 нормальним АТ порушена ВФЕ виявлена у $17,6 \%$ осіб, а серед ектоморфних ендоморфів цей показник був незначно вищим, порушення ВФЕ встановлено у $20 \%$ представників цього соматотипу. Найбільша кількість осіб із порушеною вазомоторною функцією ендотелію виявлена серед мезоморфних ендоморфів КГ, вони складали 26 \% (рис. 1). 


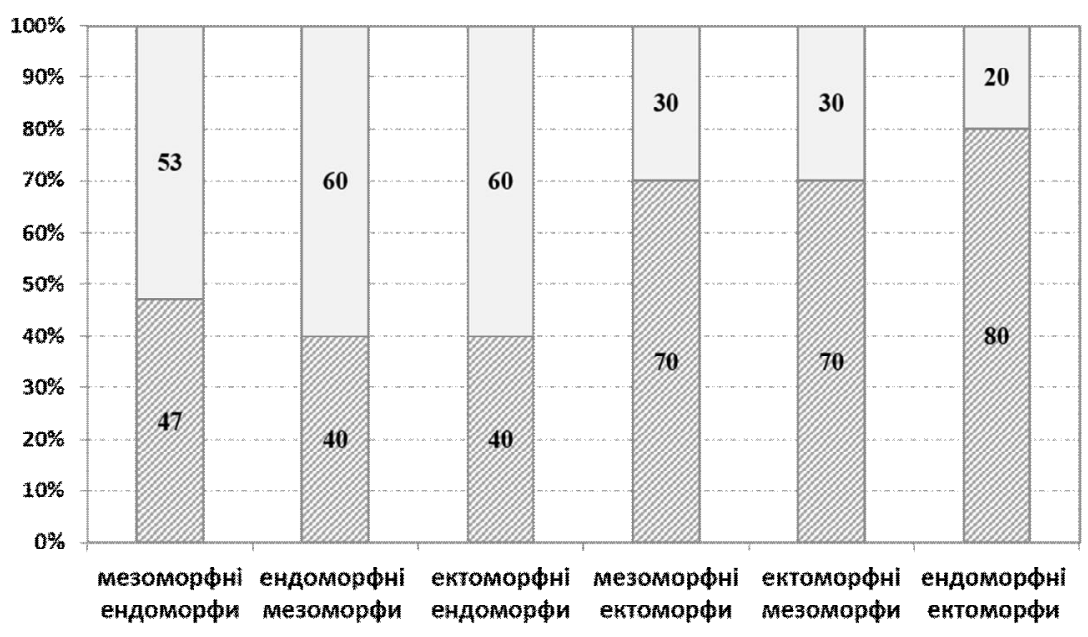

$\square$ Порушена ВФЕ Шормальна ВФЕ

Рис. 2. Стан вазомоторної функції ендотелію судин після проведення проби з постоклюзивною реактивною гіперемісю в осіб різних соматотипів 3 підвищеним АТ.

При проведенні проби з постоклюзивною реактивною гіперемією в мезоморфних ендоморфів контрольної групи, середнє значення відносного приросту амплітуди основної хвилі реовазограми кисті відповідало нормальній ВФЕ і становило $48,13 \%$, тоді, як в осіб цього ж соматотипу з підвищеним АТ - 18,17 \%, що свідчило про порушення ВФЕ.

У мезоморфних ектоморфів приріст показника складав 45,68\% серед осіб КГ та 40,62 \% серед обстежених із підвищеним АТ, що в обох групах свідчило про нормальну ВФЕ.

Порушення вазомоторної функції ендотелію виявлено в ендоморфних мезоморфів, оскільки середнє значення приросту основної хвилі реовазограми було $16,88 \%$, проте в осіб цього ж соматотипу КГ порушення ВФЕ не виявлено, приріст складав 52,42 \%.

Серед ектоморфних ендоморфів зареєстровано порушення ВФЕ в обстежених 3 підвищеним АТ, у них середнє значення приросту основної хвилі реовазограми складало $21,37 \%$, у той час як в осіб КГ приріст становив 54,12\%, тому в них ВФЕ не порушена.

В обстежених ендоморфних ектоморфів обох груп порушення вазомоторної функції не виявлено, оскільки середнє значення приросту основної хвилі реовазограми в КГ було 54,38 \%, а в групі з підвищеним тиском $-33,77 \%$.

Середнє значення приросту основної хвилі реовазограми в ектоморфних мезоморфів контрольної групи складало 50,09 \% і 33,89 \% у групі 3 підвищеним артеріальним тиском, що свідчило про нормальну вазомоторну функцію ендотелію.

В обстежених мезоморфних ендоморфів 3 підвищеним АТ нормальна ВФЕ встановлена у 46,7 $\%$, а порушення ВФЕ зафіксовано у 53,3\% осіб цього соматотипу. Також погіршення ВФЕ виявлено у $60 \%$ представників ендоморфних мезоморфів і ектоморфних ендоморфів $з$ підвищеним АТ. У 70 \% мезоморф- них ектоморфів та ектоморфних мезоморфів встановлено нормальну ВФЕ. У обстежених ендоморфних ектоморфів кількість осіб з нормальною ВФЕ склала $80 \%$.

Обговорення результатів. Отже, нами встановлено збільшення частоти розвитку дисфункції ендотелію у молодих осіб, у соматотипі яких переважав ендоморфний компонент. Це може бути пов'язано із зменшенням продукції оксиду азоту, що зумовлює дисбаланс між вазоконстрикторами і вазодилятаторами. Зниження концентрації оксиду азоту у цих осіб може бути спричинено зменшенням активності NO-синтетази (NOS) [13], що існує в трьох ізоформах: нейрональна (nNOS, NOS I), ендотеліальна (eNOS, NOS III) і макрофагальна (iNOS, NOS II). Рівень експресії перших двох форм $є$ майже постійними протягом життя і визначається генетично, тоді, як продукція макрофагальної NOS залежить від екзота ендогенних чинників. Таким чином, можна зробити припущення, що в осіб ендоморфного соматотипу $\epsilon$ певна генетична схильність до зниження продукції NOS порівняно 3 іншими соматотипами. Також потрібно враховувати, що конституційною особливістю осіб ендоморфного соматотипу є компонентне переважання жирової тканини, що, як правило, зумовлює надлишкову вагу внаслідок зменшення фізичної активності. Гіподинамія $є$ одним із вагомих чинників зменшення продукції NOS, що підтверджено багатьма дослідженнями [14,15].

\section{Висновки:}

1. У молодих осіб з підвищеним артеріальним тиском та переважанням ендоморфної складової в соматотипі встановлено зниження вазомоторної функції ендотелію, що вказує на зменшення синтезу оксиду азоту ендотеліальними клітинами, що може бути спричинено як конституційними характеристиками, так і особливостями способу життя у цих осіб.

2. Серед осіб із нормальним артеріальним тиском та 3 переважанням ендоморфної складової соматотипу також виявлено зниження вазомоторної функції ен- 
дотелію, проте відсоток таких обстежених був істотно нижчим, порівняно із групою підвищеного артеріального тиску.

\section{References:}

1. Maltais S, Perrault LP, Ly HQ. The bone marrowcardiac axis: role of endothelial progenitor cells in heart failure. Eur J Cardiothorac Surg. 2011; 39:368-374.

2. Mohylnyk AI, Shumeiko OH. Cuchasni uiavlennia pro endotelialnu dysfunktsiiu. [Current concepts of endothelial dysfunction]. Aktualni problemy suchasnoi medytsyny: Visnyk ukrainskoi medychnoi stomatolohichnoi akademii. 2013; $13(2$ (42)):268-72.

3. Zahorodnyi MI, Kaplinskyi SP. Oksyd azotu: rol u patohenezi arterialnoi hipertenzii. [Nitric oxide: role in the pathogenesis of hypertension]. Ukrainskyi kardiolohichnyi zhurnal. 2009; (4):92-7.

4. Biletskyi SV, Boiko VV, Petrynych OA, Kazantseva TV. Endotelialna dysfunktsiia ta arterialna hipertenziia (ohliad literatury). [Endothelial dysfunction and hypertension (literature review)]. Klinichna ta eksperymentalna patolohiia. 2017; 16(1 (59)):160-3.

5. Serkova VK, Voznjuk LA. Prognosticheskaja znachimost' opredelenija urovnja markerov vospalitel'noj reakcii pri ocenke riska neblagoprijatnogo techenija ishemicheskoj bolezni serdca. [Prognostic significance of determining the level of markers of inflammatory response in assessing the risk of adverse course of coronary heart disease]. Visnyk problem biolohii $\mathrm{i}$ medytsyny. 2009; (2):91-94.

6. Zahorodnyi, M I Svintsitskyi IA. Endotelialna dysfunktsiia pry arterialnii hipertenzii: suchasni pohliady na prychyny y mekhanizmy rozvytku, diahnostyku ta korektsiiu. [Endothelial dysfunction in hypertension: current views on causes and mechanisms of development, diagnosis and correction]. Praktykuiuchyi likar. 2013; (2):17-27.

7. Koshlia VI, Muna B. Endotelialna dysfunktsiia pry arterialnii hipertenzii. [Endothelial dysfunction in hypertension]. Simeina medytsyna. 2016; (2 (64)):93-4.

8. Skyba OO. Osoblyvosti pokaznykiv kardiointervalohrafii u ditei iz riznym somatotypom i typom vehetatyvnoi rehuliatsii. [Features of cardiointervalography indices in children with different somatotype and type of vegetative regulation]. Aktualni problemy suchasnoi medytsyny. 2016; 16(2 (54)):182-7.

9. Rubinshtein R, Kuvin JT, Soffler M. Assessment of endothelial function by non-invasive peripheral arterial tonometry predicts late cardiovascular adverse events. Eur Hear J. 2010; 31:1142-1148.

10. Svishchenko YeP, Bahrii AE, Yena LM. Rekomendatsii Ukrainskoi asotsiatsii kardiolohiv $\mathrm{z}$ profilaktyky ta likuvannia arterialnoi hipertenzii. [Recommendations of the Ukrainian Association of Cardiologists for the Prevention and Treatment of Hypertension]. Kyiv: PP VMB; 2008. P.72.

11. Carter JEL, Heath BH. The Heath-Carter Anthropometric Somatotype. Somat Instr Man. 2002;(March):1-26.

12. Rogoza AN, Zairova AR, Oshhepkova EV. Sposob ocenki vazomotornoj funkcii jendotelija $\mathrm{s}$ primeneniem reovazografii. [Method for evaluating vasomotor endothelial function using rheovasography]. №2010103759.

13. Forstermann U, Sessa WC. Nitric oxide synthases: regulation and function. Eur Hear J. 2012; 33:829-37.

14. Rankovic G, Djindjic N, Rankovic-Nedin G. The effects of physical training on cardiovascular parameters, lipid disorders and endothelial function. Vojn Pregl. 2012; 69:956-60.

15. Haram PM, Kemi OJ, Wisloff U. Adaptation of endothelium to exercise training: insights from experimental studies. Front Biosci. 2008; 13:336-46.

УДК 616.12-008.331-06:616.13-018.74-053.7/.82

ВАЗОМОТОРНАЯ ФУНКЦИЯ ЭНДОТЕЛИЯ У МОЛОДЫХ ЛИЦ РАЗНОГО СОМАТОТИПА С НОРМАЛЬНЫМ И ПОВЫШЕНЫМ АРТЕРИАЛЬНЫМ ДАВЛЕНИЕМ

\section{С.Н. Вадзюк, Л.И. Горбань, И.Я. Папинко}

Тернопольский национальньй медицинский университет им. И.Я. Горбачевского, кафедра физиологии с основами биоэтики и биобезопасности,

2. Тернополь, Украина,

ORCID ID: 0000-0001-9105-8205,

e-mail:vadzyuk@tdmu.edu.ua,

ORCID ID: 0000-0002-8572-239X,

e-mail:horban@tdmu.edu.ua,

ORCID ID: 0000-0001-6129-0097,

e-mail:papinko@tdmu.edu.ua

Резюме. Цель работы - оценить вазомоторную функцию эндотелия у молодых лиц в возрасте 18-22 года разного соматотипа с нормальным и повышенным артериальным давлением (АД).

Материалы и методы исследования. Отобраны две группы обследуемых: первая контрольная группа - лица, у которых величина АД отвечала оптимальному уровню (125 человек), вторая группа - систолическое АД превышал 130 мм рт. ст. и (или) диастолическое - 85 мм рт. ст. (135 человек). Соматотип определяли по методике Carter i Heath, которая рекомендована для лиц обоего пола в возрасте от 14 до 70 лет и является наиболее распространенной на сегодня. Оценку вазомоторной функции эндотелия проводили с помощью пробы с постоклюзивной реактивной гиперемией, согласно методике Рогозы и Заировои (2011).

Результаты. Установлено увеличение частоты развития дисфункции эндотелия у молодых лиц, в соматотипе которых преобладал эндоморфный компонент. Это может быть связано с уменьшением продукции оксида азота, что приводит к дисбалансу между вазоконстрикторами и вазодилятаторами. Снижение концентрации оксида азота в этих лиц может быть вызвано уменьшением активности NO-синтетазы (NOS).

Выводы. У молодых лиц с повышенным артериальным давлением и преобладанием эндоморфной составляющей в соматотипе установлено 
снижение вазомоторной функции эндотелия, что указывает на уменьшение синтеза оксида азота эндотелиальными клетками, что может быть вызвано как конституционными характеристиками, так и особенностями образа жизни у этих лиц. Среди лиц с нормальным артериальным давлением и с преобладанием эндоморфной составляющей соматотипа также выявлено снижение вазомоторной функции эндотелия, однако процент таких обследованных был существенно ниже по сравнению с группой повышенного артериального давления.

Ключевые слова: артериальное давление, артериальная гипертензия, эндотелий, вазомоторная функция эндотелия, соматотип.

UDC 616.12-008.331-06:616.13-018.74-053.7/.82

VASOMOTOR FUNCTION OF THE ENDOTHELIUM IN YOUNG PEOPLE OF DIFFERENT SOMATOTYPE WITH NORMAL AND HIGH BLOOD PRESSURE

\section{S.N. Vadzyuk, L.I. Horban, I.Ya. Papinko}

Ya. Horbachevsky Ternopil National Medical University, Department of Physiology with basics of Bioethics and Biosafety, Ternopil, Ukraine, ORCID ID: 0000-0001-9105-8205, e-mail:vadzyuk@tdmu.edu.ua, ORCID ID: 0000-0002-8572-239X, e-mail:horban@tdmu.edu.ua, ORCID ID: 0000-0001-6129-0097, e-mail:papinko@tdmu.edu.ua

Abstract. The aim of the study was to evaluate vasomotor endothelial function in young people, 18-22 years of age, of different somatotype with normal and high blood pressure (BP).

Materials and methods of research. Two groups of subjects were selected: the first control group - subjects in which the value of blood pressure corresponded to the optimal level (125 surveyed), the second group - systolic blood pressure exceeded 130 $\mathrm{mmHg}$ and (or) diastolic - $85 \mathrm{mmHg}$ (135 people). Somatotype was determined by the method of Carter and Heath, which is recommended for people of both sexes between the ages of 14 and 70 and is the most common today. The evaluation of vasomotor function of the endothelium was performed using a postexclusive reactive hyperemia test according to the method of Rogoza and Zairova (2011). The survey was conducted by computer rheographic complex «Reocom» (manufactured at scientific and technical center «KAI-Medica» Kharkiv, Ukraine). The rheovasogram $(\mathrm{RVG})$ of the right hand was recorded at baseline for 5 minutes, before which the baseline blood pressure (two measurements) was measured. Subsequently, air was pumped into the occlusal cuff for 5 minutes with a pressure that exceeded the value of systolic blood pressure by $50 \mathrm{mmHg}$ and within 5 minutes of occlusion, blood pressure was monitored (two measurements). After a sharp decompression during the next 5 minutes continued to register RVG in the period of post-exclusive reactive hyperemia, and also monitored the level of blood pressure (three measurements). Evaluation of vasomotor function of endothelium was performed according to the index of the relative amplitude of the main wave of the rheovasogram of the hand to the initial value. An increase of more than $23.2 \%$ testified to normal vasomotor function and at a value less than $23.2 \%$ of impaired vasomotor function of the endothelium.

Results. Therefore, we found an increase in the incidence of endothelial dysfunction in young individuals with dominated endomorphic component in the somatotype. This may be due to a decrease in nitric oxide production, which causes an imbalance between vasoconstrictors and vasodilators. The decrease in the concentration of nitric oxide in these individuals can be caused by a decrease in the activity of NO synthetase (NOS), which exists in three isoforms: neuronal (nNOS, NOS I), endothelial (eNOS, NOS III) and macrophage (iNOS, NOS II). The expression level of the first two forms is almost constant throughout life and is genetically determined, whereas the production of macrophage NOS depends on exogenous and endogenous factors. Thus, it can be assumed that individuals with an endomorphic somatotype have a certain genetic tendency to reduce NOS production compared to other somatotypes. It should also be borne in mind that the constitutional feature of individuals with endomorphic component of somatotype is the predominance of adipose tissue, which usually causes excess weight due to a decrease in physical activity.

Conclusions. In young people with high blood pressure and predominance of the endomorphic component in somatotype, a decrease in vasomotor function of the endothelium was found, which indicates a decrease in the synthesis of nitric oxide by endothelial cells, which can be caused by both constitutional characteristics and lifestyle features. Among subjects with normal blood pressure and with predominance of the endomorphic component of somatotype, there was also a decrease in vasomotor function of the endothelium, but the percentage of such examinations was significantly lower, compared with the group of high blood pressure.

Keywords: blood pressure, arterial hypertension, endothelium, vasomotor function of endothelium, somatotype.

Стаття надійшла в редакцію 31.10.2019 р. 